\title{
The immune system and the impact of zinc during aging
} Hajo Haase and Lothar Rink*

\author{
Address: Institute of Immunology, Medical Faculty, RWTH Aachen University Pauwelsstrasse 30, 52074 Aachen, Germany \\ Email: Hajo Haase - hhaase@ukaachen.de; Lothar Rink* - lrink@ukaachen.de \\ * Corresponding author
}

Published: 12 June 2009

Immunity \& Ageing 2009, 6:9 doi: 10.1 I86/1742-4933-6-9

This article is available from: http://www.immunityageing.com/content/6/1/9

This is an Open Access article distributed under the terms of the Creative Commons Attribution License (http://creativecommons.org/licenses/by/2.0), which permits unrestricted use, distribution, and reproduction in any medium, provided the original work is properly cited.

\begin{abstract}
The trace element zinc is essential for the immune system, and zinc deficiency affects multiple aspects of innate and adaptive immunity. There are remarkable parallels in the immunological changes during aging and zinc deficiency, including a reduction in the activity of the thymus and thymic hormones, a shift of the $\mathrm{T}$ helper cell balance toward $\mathrm{T}$ helper type 2 cells, decreased response to vaccination, and impaired functions of innate immune cells. Many studies confirm a decline of zinc levels with age. Most of these studies do not classify the majority of elderly as zinc deficient, but even marginal zinc deprivation can affect immune function. Consequently, oral zinc supplementation demonstrates the potential to improve immunity and efficiently downregulates chronic inflammatory responses in the elderly. These data indicate that a wide prevalence of marginal zinc deficiency in elderly people may contribute to immunosenescence.
\end{abstract}

\section{Review}

Introduction

The human body contains 2-3 g zinc, most of which is bound to proteins. Over 300 enzymes have been shown to contain zinc, either directly involved in catalysis, as a cofactor, or for structural stabilization [1]. Another large group of zinc containing proteins are transcription factors, many of which contain zinc fingers and similar structural motives. From in silico studies searching for known zincbinding patterns, it has been estimated that approximately $10 \%$ of the human genome encode for proteins that could bind zinc [2].

Severe zinc deficiency is characterized by growth retardation, skin lesions and impaired wound healing, hypogonadism, anemia, diarrhea, anorexia, mental retardation, and impaired visual and immunological function $[3,4]$.
Notably, also during milder forms of zinc deficiency an effect on immunity is observed.

On the cellular level, zinc is essential for proliferation and differentiation, but zinc homeostasis is also involved in signal transduction [5,6] and apoptosis [7]. Cells depend on a regular supply of zinc and make use of a complex homeostatic regulation by many proteins [8], but the plasma pool, which is required for the distribution of zinc, represents less than one percent of the total body content [1]. Despite its important function, the body has only limited zinc stores that are easily depleted and can not compensate longer periods of zinc deficiency. Additionally, during infections pro-inflammatory cytokines mediate changes in hepatic zinc homeostasis, leading to sequestration of zinc into liver cells and subsequently to hypozincemia [9]. Alterations in zinc uptake, retention, 
sequestration, or secretion can quickly lead to zinc deficiency and affect zinc-dependent functions in virtually all tissues, and in particular in the immune system.

\section{Role of zinc in the immune system}

The trace element zinc is essential for growth and development of all organisms and the high rate of proliferation and differentiation of immune cells necessitates a constant supply with sufficient amounts of zinc. In the following section, we will discuss the different roles of zinc in the immune system.

In a review by Beisel, the effects of zinc deficiency on immunity in animal models are summarized [10]. The effects are hypoplasia of lymphoid tissues, and reductions in T-helper cell numbers, NK cell activity, antibody production, cell mediated immunity, and phagocytosis [10]. In humans, the most prominent example for the effects of zinc deficiency is acrodermatitis enteropathica, a rare autosomal recessive inheritable disease that causes thymic atrophy and a high susceptibility to bacterial, fungal, and viral infections [11]. It is a zinc-specific malabsorption syndrome based on a mutation within the gene for the intestinal zinc transport protein hZip4 $[12,13]$. All symptoms can be reversed by nutritional supplementation of excess zinc. Zinc deficiency does not affect just a single component of the immune system; the effects are complex, occur on many levels, and involve the expression of several hundred genes $[14,15]$. Short term effects include the regulation of the biological activity of thymulin by the plasma zinc status, while long term effects can lead to changes in immune cell subpopulations [16]. Even epigenetic effects were observed [17]. Gestational zinc deficiency in mice not only depressed the immune function of the offspring of these mice, but to a lesser extent compromised immune function was still found in the second and third filial generation, even though these mice had been fed with a zinc sufficient diet [17].

One major mechanism by which zinc affects immunity is its role as a signaling ion (figure 1). The intracellular concentration of free zinc is regulated by three mechanisms. One is transport through the plasma membrane [5]. Another mechanism involves storage in and release from vesicles, so-called zincosomes, in which zinc is stored as a complex with multiple ligands [18]. Finally, zinc binds to metallothionein (MT). Through its 7 binding sites with different affinities, MT buffers zinc in the pico- to nanomolar range, and can additionally be controlled by release of zinc by oxidation of zinc-binding cysteine thiol residues [19].

Zinc signals, i.e. changes in the intracellular concentration of free zinc mediated by these three mechanisms, act on immune cell signal transduction [20]. The first example was protein kinase $\mathrm{C}$ (PKC), which has been identified as a molecular interaction partner for zinc in $\mathrm{T}$ cells [21]. Its $\mathrm{N}$-terminal regulatory domain contains four $\mathrm{Cys}_{3} \mathrm{His}$ zinc binding motifs. Zinc treatment stimulates PKC kinase activity, its affinity to phorbol esters, and binding to the plasma membrane and cytoskeleton. Furthermore, zinc chelators inhibit the induction of these events by physiological activators of PKC [20].

The lymphocyte protein tyrosine kinase (Lck), a Src-family tyrosine kinase, is an example for a different mechanism by which zinc acts on signal transduction. Zinc ions promote activation of Lck and its recruitment to the T cell receptor complex by linking two protein interface sites. The N-terminal region of Lck is recruited to the intracellular domains of the membrane proteins $\mathrm{CD} 4$ or $\mathrm{CD} 8$ by a 'zinc clasp' structure [22-24]. At the second zinc-dependent interface site two zinc ions at the dimer interface of the SH3 domains stabilize homodimerization of Lck, which is thought to promote autophosphorylation required for its activation [25].

Zinc signals were also observed when monocytes were treated with lipopolysaccharide. These zinc signals regulate inflammatory signaling [26]. Here, cyclic nucleotide phosphodiesterases and MAPK phosphatases were identified as molecular targets of zinc [26-28]. Signaling via the transcription factor NF- $\kappa \mathrm{B}$ is also dependent on zinc signals; however, in this case it is no direct interaction with zinc, but rather a regulation of upstream signaling pathways leading to the activation of NF- $\mathrm{KB}$ [26].

Recent papers demonstrate an influence of zinc transporters on signal transduction. Zrt/Irt-like protein (ZIP)7 releases $\mathrm{Zn}$ from the ER, controlling tyrosine phosphorylation [29], and lysosomal ZIP8 is required for zincmediated calcineurin inhibition and interferon (IFN)- $\gamma$ expression in T cells [30]. Conversely, there also exist feedback mechanisms, which act on zinc homeostasis. The promoters of MT and of several zinc transporters are under the control of the metal-response element binding transcription factor (MTF)-1. In contrast to other transcription factors with zinc fingers that bind zinc constitutively, its DNA-binding is regulated by the stabilization of zinc finger motifs by free cellular zinc $[5,31,32]$.

Zinc deficiency in the elderly may impair zinc-dependent signaling, and thereby immune function. In one recently published study, peripheral blood mononuclear cells (PBMC) from zinc-deficient elderly showed impaired NF$\kappa \mathrm{B}$ activation and interleukin (IL)-2 production in response to stimulation with PHA, which was corrected by in vivo supplementation of zinc ( $45 \mathrm{mg} /$ day as gluconate) 


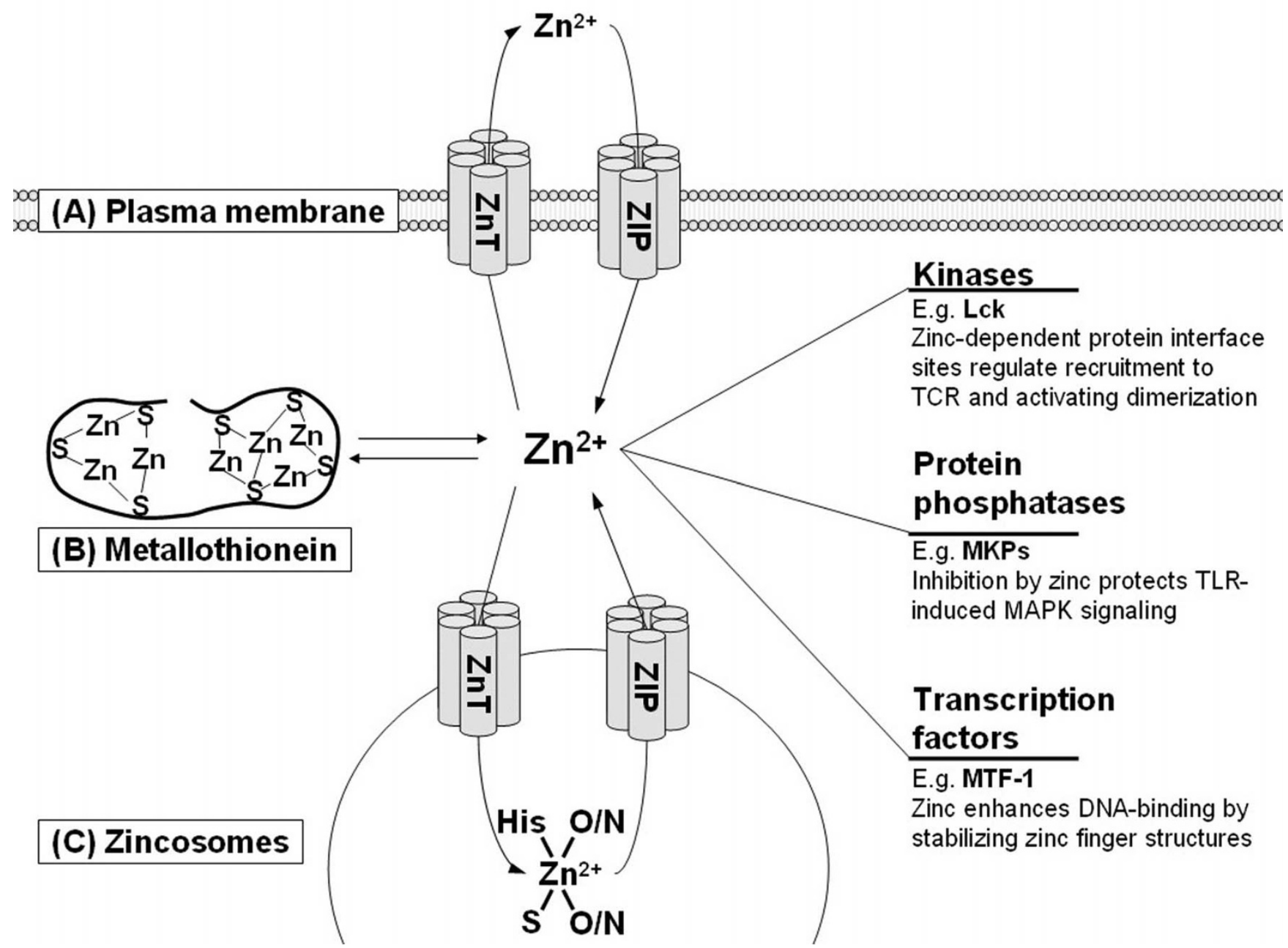

Figure I

Zinc as a signal molecule for immune cells. Zinc homeostasis is tightly controlled by three mechanisms: (A) Transport through the plasma membrane by zinc transporters from the ZnT (SLC A30) or ZIP (SLC A39) families. (B) Buffering by metallothionein. (C) Reversible transport by ZnT and ZIP proteins into or out of zincosomes, and storage bound to ligands that form a zinc sink. Zinc signals, i.e., changes in the intracellular concentration of free zinc, control immune cell signal transduction by regulating the activity of major signaling molecules, including kinases, phosphatases, and transcription factors. One representative example for each group is given. (TCR, T cell receptor; MKP, MAPK phosphatase; MTF-I, metal-response element binding transcription factor-I).

for 6 months or ex vivo supplementation of zinc to PBMC [33], indicating a link between zinc deficiency and the effect of zinc on NF-KB signaling.

\section{Zinc and innate immunity}

Zinc supplementation in vitro can trigger events required for the recruitment of leukocytes to the site of infection. For example, high zinc concentrations induce chemotaxis of polymorphonuclear cells [34], and zinc promotes the adhesion of myelomonocytic cells [35]. On the other hand, zinc deficiency in vivo causes impaired phagocytosis, parasite killing, and oxidative burst of monocytes and neutrophil granulocytes, and a decrease in NK cell activity
[36-38]. Zinc is also required for recognition of HLA-C molecules by the killer cell inhibitory receptors on $\mathrm{NK}$ cells, but, notably, zinc is only necessary for inhibitory, but not stimulatory effects [39]. Via this mechanism, zinc deficiency may promote nonspecific killing by NK cells. However, this effect is counteracted by a reduction of NK cell lytic activity in zinc deficient patients [40].

\section{Zinc and adaptive immunity}

The adaptive immune response is based on two groups of lymphocytes: B cells, which differentiate into immunoglobulin secreting plasma cells and hereby induce humoral immunity, and T cells, which mediate cytotoxic 
effects and helper cell functions of cell mediated immunity. Both responses depend on the clonal expansion of cells after recognition of their specific antigen. While B cells depend on zinc for proliferation, they do so to a lesser extent than $\mathrm{T}$ cells $[41,42]$. In addition, a heightened level of apoptosis in pre B and T cells was found in zinc deficient mice. Mature cells are more resistant to apoptosis induced by zinc deficiency, possibly because of the higher level of the anti-apoptotic protein BCL-2 in these cells [16]. Not only does zinc deficiency affect B cell lymphopoiesis, it has also been shown to lead to a reduction in antibody-mediated immune defense [16].

The most prominent effect of zinc deficiency is a decline in $\mathrm{T}$ cell function, which results from multiple causes. Thymulin, a hormone secreted by thymic epithelial cells, requires zinc as a cofactor and exists in the plasma in two forms, a zinc-bound active one, and a zinc-free, inactive form. It is essential for differentiation and function of $\mathrm{T}$ cells, which could explain some of the effects of zinc deficiency on $\mathrm{T}$ cell function. In mice, zinc deprivation reduces the level of biologically active thymulin in the circulation [43]. This effect has been observed in the absence of thymic atrophy, and thymulin activity was restored after in vitro supplementation of the serum with zinc, indicating that thymulin activity is directly dependent on serum zinc [44]. In mildly zinc deficient humans, thymulin activity was also decreased, and a comparable effect of zinc supplementation in vitro and in vivo was described [45].

Furthermore, the TH1/TH2 balance is affected by zinc. During zinc deficiency, the production of TH1 cytokines, in particular IFN- $\gamma$, IL-2, and tumor necrosis factor (TNF)$\alpha$ is reduced, whereas the levels of the TH2 cytokines IL-4, IL-6, and IL-10 were not affected in cell culture models [46] and in vivo $[47,48]$. In addition to the immunomodulatory effects of zinc deprivation, zinc supplementation can modulate $\mathrm{T}$ cell dependent immune reactions. Zinc supplementation to PBMC leads to T cell activation, an indirect effect that is mediated by cytokine production by other immune cells, but higher concentrations of zinc can also directly suppress $\mathrm{T}$ cell function. Here, zinc reduces IL-1 dependent T-cell stimulation by inhibiting the interleukin-1 receptor associated kinase-1 [49]. In vitro, zinc inhibits the mixed lymphocyte culture (MLC) [50], and a clear reduction in the MLC was also shown in PBMC from human subjects that had been supplemented with $80 \mathrm{mg}$ zinc per day for one week. Notably, the response to a recall antigen, tetanus toxoid, was unaffected in these cells and zinc specifically inhibited the allogenic reaction [51].

\section{Zinc and cytokine levels}

Zinc has been characterized as a positive and negative regulator of pro-inflammatory cytokines, in particular IL-1 and TNF- $\alpha$. Some reports describe that zinc supplementation to human peripheral blood mononuclear cells leads to an increased mRNA production and release of the monokines IL- 6 , IL- $1 \beta$, and TNF- $\alpha$, and a combination of nonstimulatory concentrations of LPS and zinc results in the production of large amounts of monokines [52]. On the other hand, several reports indicate that zinc treatment suppresses the formation of pro-inflammatory cytokines $[46,53]$. This difference can be explained by the observation that the effect of zinc is concentration dependent, and that zinc can be stimulatory or inhibitory in the same experimental system. Whereas an increase of intracellular free zinc, which can be imitated by moderate zinc supplementation to cell cultures, is a zinc signal involved in cytokine production of monocytes in response to LPS [26], higher concentrations can have an antagonistic effect by inhibition of cyclic nucleotide phosphodiesterases and a subsequent activation of protein kinase A $[27,28]$. In T cells, cytokine secretion is only indirectly affected by zinc. Zinc-induced release of IFN- $\gamma$ and the soluble IL-2 receptor depends on the presence of monocytes, and is based on direct cell to cell contact and zinc-mediated production of the monokines IL-1 and IL6 [52].

\section{Immunological changes during aging}

Aging of the immune system, also referred to as immunosenescence, describes the age-related changes in immune function that lead to increased susceptibility of older people to infectious diseases, autoimmunity, and cancer. The capacity of the immune system to mount an adequate response decreases with age, starting around 60 , but several factors such as lifestyle and underlying diseases can significantly affect the onset in each individual [54]. Interestingly, a comparison between alterations of the immune system during zinc deprivation and aging shows many similarities, indicating a possible relation between immunosenescence and zinc deficiency [55]. In both cases it comes to anergy, thymic atrophy, and reduced NK cell activity, cell mediated cytotoxicity, helper $\mathrm{T}$ cell activity and thymulin levels [56].

As it could be expected from the decline in immune function, aged patients suffer from an augmented incidence and mortality of infectious diseases such as pneumonia [57] and tuberculosis [58], and re-infections with herpes zoster increase [59]. The frequency of autoimmune diseases is augmented with age, too, accompanied by an increase in autoantibodies, which is, interestingly, not observed in centenarians $[60,61]$. On the other hand, specific IgE production decreases, reducing the risk for allergies $[62,63]$.

Cancer is a disease that occurs over proportion in elderly as well. People $\geq 65$ years have an eleven fold higher inci- 
dence of cancer and a fifteen fold higher mortality than younger subjects [64]. Although the immune system functions as a network in which nearly all elements interact with each other, some components can be identified that are especially affected by aging and whose functional impairment causes increased susceptibility for diseases like the examples mentioned above $[65,66]$.

Neutrophil granulocytes form the first line of defense against pathogens, mainly by phagocytosis, but also cytokine secretion and recruitment of other immune cells. The higher incidence of microbial infections in the elderly, although often attributed primarily to a decline in $\mathrm{T}$ cell function, may also in part be the result of an impairment of neutrophils. The total number of neutrophils is not different in the aged compared to younger controls. However, phagocytosis, oxidative burst, and intracellular killing are affected and neutrophils from the elderly show a reduction in chemotaxis and a reduced resistance toward apoptosis, based on a diminished antiapoptotic effect of stimuli such as LPS, G-CSF, and GM-CSF [67].

While the activity of all other immune cells decreases with age, some functions of macrophages, and their precursors monocytes, are even augmented in elderly. No change in the number of monocytes in the blood is observed and, in contrast to neutrophils, chemotaxis, phagocytosis, and oxidative burst remain unchanged [68]. However, their accessory function for $\mathrm{T}$ cells is impaired, although the expression of several cytokines, adhesion molecules, and HLA-DR is not altered [69]. The plasma concentrations of IL-6, IL-8, MCP-1, MIP- $1 \alpha$, and TNF- $\alpha$ are positively correlated with age [70]. Furthermore, production of proinflammatory cytokines such as IL-1, IL-6, IL-8, and TNF$\alpha$ after stimulation with LPS is significantly increased $[71,72]$. In contrast, IFN- $\alpha$, which is mainly produced by monocytes, is reduced [73]. The other major group of antigen presenting cells, dendritic cells, seem to be unaffected by age with respect to surface marker expression and transendothelial migration [74]. The total number of NK cells and their percentage among circulating cells is increased in old people, but this effect is compensated by a reduced cytotoxic activity on a per-cell basis and reduced proliferation in response to IL-2 [75-77], together with reduced calcium signaling and CD69 expression, while TNF- $\alpha$ secretion remains unaffected [78]. Because the main functions of NK cells are the elimination of cancer or virus infected cells, the higher incidence of viral infections and cancer in the elderly may well be related to impairment of NK cell function.

The most severe changes during aging are found in the adaptive immune system. Aging leads to a shift in B cell populations and antibody production. B cell numbers decline with age and one would expect that this is accom- panied by a decrease in immunoglobulins, but the opposite has been observed, showing an increase of IgA and several IgG subclasses [79]. The response to vaccination with several antigens is diminished, which may result from an impaired interaction with $\mathrm{T}$ helper cells (see below), but also a loss of antibody affinity was found. At the same time an increase in organ-specific and nonorgan-specific autoantibodies was observed, but, whereas the latter increase with age, subjects over 90 years show lower levels of organ-specific autoantibodies than younger elderly [80]. Another change that occurs with age is increased clonal expansion of B cells, which may be connected to the increased incidence of lymphocyte malignancies with age [80]. The effects of aging on B cells and humoral immunity are summarized in figure 2 .

Similar to the effects of zinc deficiency, the main changes of aging also affect the $\mathrm{T}$ cell system. T cells from elderly subjects show decreased proliferation in response to $\mathrm{T}$ cell receptor (TCR) stimulation or mitogens [81], an altered CD4/CD8 ratio, and higher expression of CD95 and the pro-apoptotic BAX combined with a decrease in BCL-2 and $\mathrm{p} 53$, which leads to increased apoptosis [82]. A prominent feature of immunosenescence is thymic involution. This leads to a decrease in the generation of new T cells, finally resulting in a lower number of naïve (CD45RA+) and a higher number of memory (CD45R0+) T cells [83]. Zinc deficiency can also cause thymic involution, regardless of age. A reduction of zinc availability induces higher levels of thymocyte apoptosis, either by elevating glucocorticoid production or because zinc has a negative regulatory function in immune cell apoptosis $[16,20,84]$. Notably, supplementation of the drinking water of old mice with zinc sulfate has been reported to induce an increase in thymic mass [85], and parameters such as thymic weight, the number of viable thymocytes, and serum thymulin activity were restored by oral zinc supplementation [86]. Hence, lower zinc levels in the elderly could contribute to thymic involution by augmenting apoptosis during $\mathrm{T}$ cell maturation and selection in the thymus.

As in B cells, monoclonal expansion has been found for T cells from elderly subjects. The expanded subsets can make up a large fraction of T cells, but no signs of malignant transformation have been reported [87]. The expanded subsets were primarily CD8 positive whereas CD4 populations remained unchanged. However, T helper cells are also affected by aging, showing a decreased $\mathrm{TH} 2 / \mathrm{TH} 1$ ratio in the elderly, measured by CCR4/CCR 5 surface expression [88]. In addition, alterations in the balance of TH1/TH2 cytokines occur that are similar to the effects observed during zinc deprivation [88]. The TH1 cytokines IFN- $\gamma$, IL-2, and sIL-2R are reduced. In contrast, 


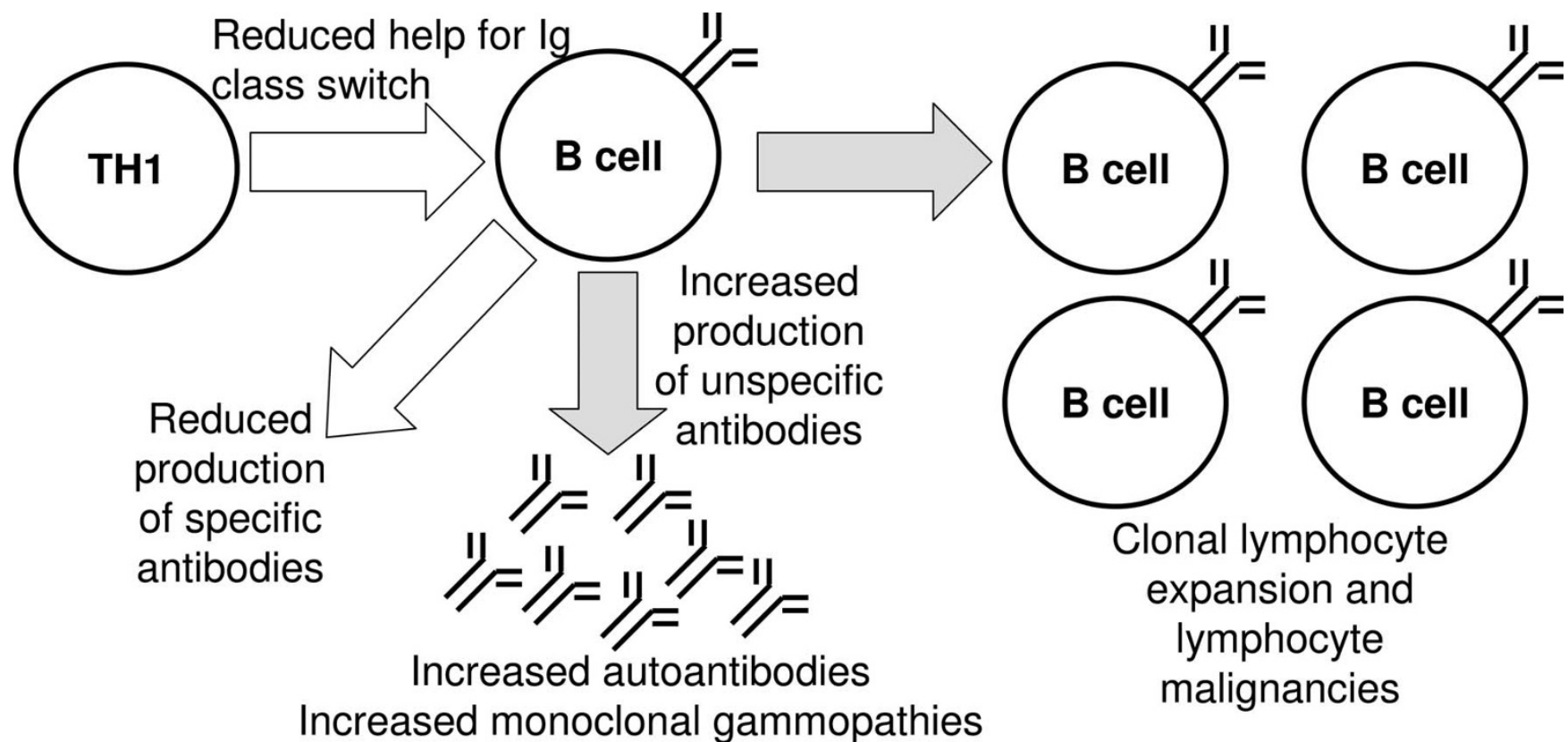

\section{$\square$ Increases with age $\longrightarrow$ Decreases with age}

\section{Figure 2}

Disturbed B-cell function in ageing. In general, the numbers of B cells and specific antibodies (e.g., in response to vaccination) decrease with age, while total and unspecific immunoglobulin and autoantibodies increase. Some B cell clones expand, resulting in higher probability for lymphocyte malignancies.

TH2 cytokines IL- 4 and IL-10 are increased, resulting in a shift toward TH2 cytokines [89,90].

Decreased humoral immunity may not only result from changes in B cells, but in part be caused by a disturbance of $\mathrm{T}$ cell help and alterations of cytokine levels, because many cytokines that control B cell functions are affected by aging [90,91]. As summarized in figure 3, a disturbed humoral response may be the result of a combination of an impaired interaction between antigen presenting cells (APC) and Thelper cells and a shift in the TH1/TH2 balance, which both add to the immunological alterations that occur directly in B cells. It is noteworthy that zinc can antagonize all these effects: Zinc supplementation can suppress the release of pro-inflammatory cytokines from LPS-stimulated monocytes [27], and addition of zinc to PBMC promotes IFN- $\gamma$ release [92]. In vitro zinc supplementation can also decrease IL-10 release [93] and restore IFN- $\alpha$ production from leukocytes of elderly subjects [73]. However, the effect of zinc is not limited to cytokine expression, because the antiviral activity of IFN- $\alpha$, but not IFN- $\beta$ and $-\gamma$, is potentiated by addition of zinc in vitro [94].

\section{Zinc status of the elderly}

Many micronutrients affect immunity and suboptimal nutritional supply can cause an impaired immune response [95]. This is especially true for zinc, given its essential role in many immunological processes, as described above. In many elderly, the required supply of zinc is not met [96]. A multitude of influencing factors has been suggested, which include physiological, social, psychological, and economic factors. For example, reduced mobility leads to a decrease in energy requirements. The resulting consumption of smaller quantities of food also means consuming lower amounts of trace elements, including zinc. In addition, decreased intestinal absorption, which in part depends on the composition of the food, and medication like diuretics, could cause a negative zinc balance, even if there is sufficient uptake. All these factors together can result in insufficient nutritional supply with trace metals in the elderly [4]. Finally, some diseases that occur with increased frequency in older people, such as diabetes, are also accompanied by zinc deficiency $[4,97,98]$.

The recommended daily allowance (RDA) for zinc in individuals 19 years and older (special recommendations for elderly do not exist) in the United States is $11 \mathrm{mg} /$ day for men and $8 \mathrm{mg} /$ day for women [98]. An uptake below the RDA can only be seen as an indicator of potential zinc deficiency, because many other factors also play a role and the possibility exists that the metabolism may adapt to decreased zinc intake. Hence, it is necessary to analyze the 

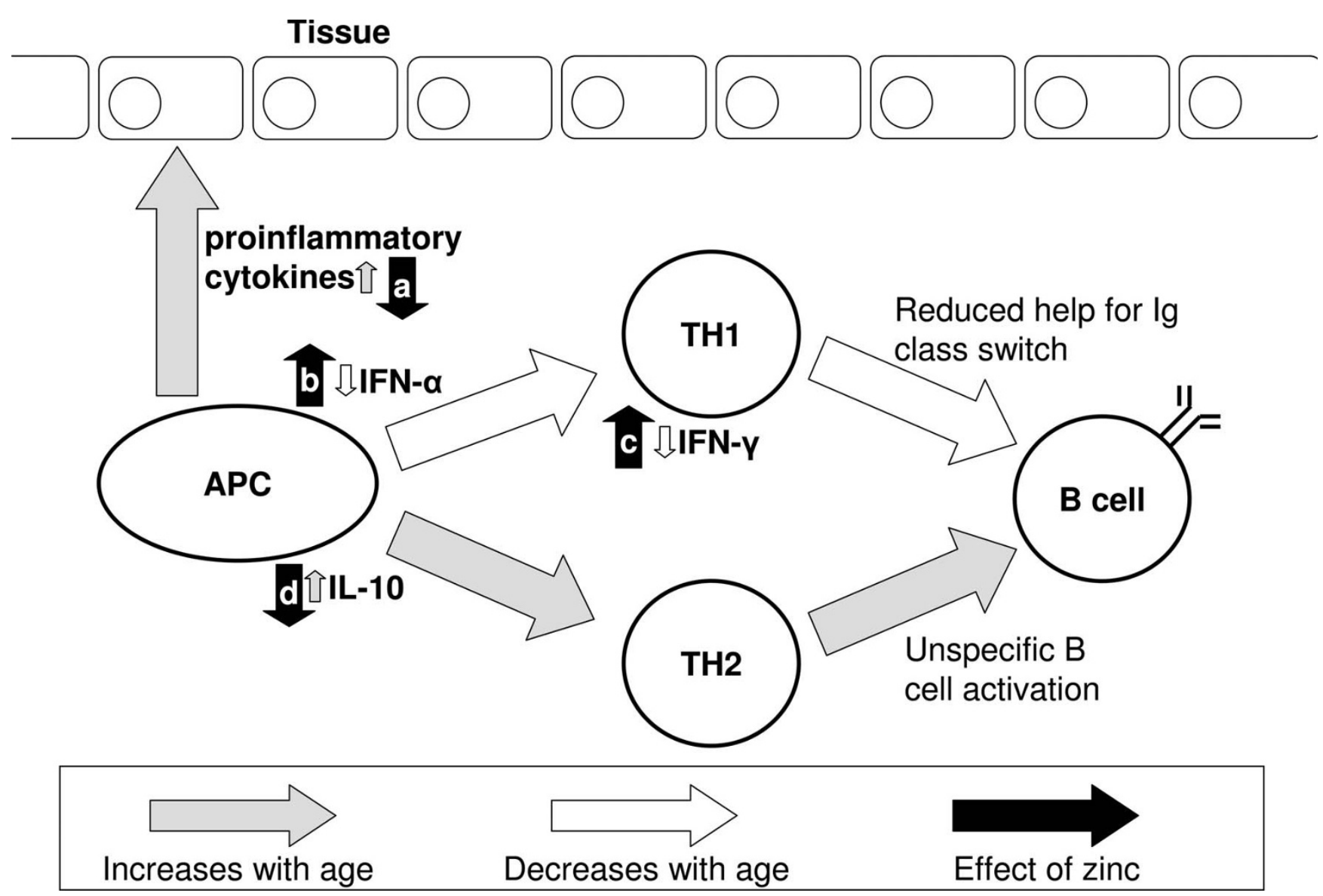

Figure 3

Influence of zinc on age-related changes of immune function. Aging leads to an increase in pro-inflammatory cytokines and modulates the THI-TH2 balance toward a TH2 response by reducing the TH-I cytokines IFN- $\alpha$ and $-\gamma$ and increasing IL10. This reduces $T$ cell help for immunoglobulin class switch and causes unspecific activation of $B$ cells. Zinc counteracts the effects on [a] pro-inflammatory cytokines [27], [b] IFN- $\alpha$ [73], [c] IFN- $\gamma$ [92], and [d] IL-I0 [93].

zinc status of the individual. The parameter of choice is often serum or plasma zinc. However, this is not an ideal parameter for determining the zinc status. When zinc deficiency was experimentally induced in young subjects, they showed significant effects on the production of IFN- $\gamma$, IL2 , and TNF- $\alpha$ with an imbalance in the TH1/TH2 system, but plasma zinc was not significantly affected [47]. Whereas reduced plasma or serum zinc levels can indicate zinc deficiency, such deficiency can also occur at levels that are within the reference values [98]. Possibly, other parameters, such as labile intracellular zinc in leukocytes, will be a more accurate measure for the zinc status in the future [99].

Many studies about zinc nutrition and status in the elderly exist (table 1). In most of these studies, zinc deficiency is defined as a serum or plasma concentration below 10.7 $\mu \mathrm{M}$, which corresponds to $70 \mu \mathrm{g} / \mathrm{dL}$. In most cases a clear tendency toward suboptimal zinc intake and decreasing zinc plasma and serum levels with age were found, but values were still within the reference range of $70-110 \mu \mathrm{g} /$ dL. An early study in 1971 investigated the correlation between age and plasma zinc in 204 male subjects between the ages of 20 to 84 , and 54 female subjects between 20 and 58, finding a significant linear decrease of plasma zinc with age in both groups [100]. In contrast, red blood cell zinc content was even slightly increased, although these effects were not significant [100]. A significant reduction in serum zinc was also found for the 'oldest old' ( $\geq 90$ years), compared to healthy elderly between 65 and 89 years and adults between 20 to 64 years [101]. Three other studies did also not find a high prevalence of zinc deficiency in the elderly, but while not being deficient, in one study mean plasma levels were low $(<85 \mu \mathrm{g} /$ dL) [102], in another serum zinc levels were significantly below a young control group [89], and erythrocyte zinc concentration was lower in 70-85 year olds, compared to a group between 55 and 70 years [103]. 
Table I: Zinc status of the elderly.

\begin{tabular}{|c|c|c|}
\hline Subjects & Zinc status & Reference \\
\hline $\begin{array}{l}204 \text { males, } 20-84 \text { y. } \\
54 \text { females, } 20-58 \text { y. }\end{array}$ & significant decrease of plasma zinc, but not erythrocyte zinc, with age & {$[100]$} \\
\hline I46 elderly, 65-95 y. & mean plasma levels below $85 \mu \mathrm{g} / \mathrm{dL}(=13 \mu \mathrm{M})$ & {$[102]$} \\
\hline 121 elderly, 60-97 y. & Average zinc intake $7.3 \mathrm{mg} / \mathrm{day}, 6 \%$ had serum zinc under $70 \mu \mathrm{g} / \mathrm{dL}(=10.7 \mu \mathrm{M})$ & [132] \\
\hline $\begin{array}{l}24 \text { healthy, } 69-85 \text { y. } \\
50 \text { controls, } 21-64 \text { y. }\end{array}$ & reduced plasma zinc compared to young controls & {$[106]$} \\
\hline 20 chronically ill elderly, $70-85$ y. & $\begin{array}{l}\text { compared to Bunker et al. } 1984 \text { no effect on plasma and whole blood zinc, but reduction of } \\
\text { leukocyte zinc }\end{array}$ & {$[107]$} \\
\hline 100 elderly, 60-89 y. & $14.7 \%$ zinc deficient $(<10.7 \mu \mathrm{M}$, plasma), $>90 \%$ had intake below RDA $(15 \mathrm{mg} / \mathrm{ml}$ in 1987$)$ & [123] \\
\hline $\begin{array}{l}23 \text { elderly, } 65-85 \text { y. } \\
13 \text { controls, } 23-45 \text { y. }\end{array}$ & IL-2 production was lower in elderly with reduced leukocyte and neutrophil zinc & [126] \\
\hline $\begin{array}{l}232 \text { hospitalized, } 60-104 \text { y. } \\
25 \text { free living, 69-94 y. }\end{array}$ & serum and leukocyte zinc lower in hospitalized subjects & [122] \\
\hline 53 healthy elderly, 64-95 y. & $\begin{array}{l}\text { serum zinc decreases with age, mean serum zinc within normal range, } 65 \% \text { had intake less than } 2 / \\
3 \text { RDA }\end{array}$ & {$[105]$} \\
\hline $\begin{array}{l}19 \text { healthy, } 51.3 \text { m.a. } \\
25 \text { healthy, } 77.7 \text { m.a. } \\
30 \text { hospitalized, } 80.8 \text { m.a. } \\
34 \text { w/ulcers, } 81.3 \text { m.a. }\end{array}$ & $\begin{array}{l}\text { plasma zinc negatively correlated with age, plasma and leukocyte zinc lower in hospitalized elderly } \\
\text { compared to both healthy control groups }\end{array}$ & {$[121]$} \\
\hline $\begin{array}{l}30 \text { patients, } 72-98 y . \\
12 \text { healthy, } 75-86 y . \\
23 \text { controls, } 18-55 y .\end{array}$ & $\begin{array}{l}\text { plasma zinc significantly decreased in both groups of elderly, zinc is lowered in } \\
\text { polymorphonuclear but not mononuclear cells of elderly patients }\end{array}$ & [116] \\
\hline II 8 subjects, $50-80$ y. & decrease in lymphocyte and granulocyte zinc, $\sim 30 \%$ defined as zinc deficient & [115] \\
\hline $\begin{array}{l}21 \text { elderly, } 70-90 \text { y. } \\
20 \text { young, } 20-35 \text { y. }\end{array}$ & significantly lower serum zinc in the elderly & [89] \\
\hline 81 hospitalized, 65-102 y. & $61 \%$ of subjects zinc deficient $(<10.7 \mu \mathrm{M})$ & [119] \\
\hline 345 elderly, $>70$ y. & $\begin{array}{l}19 \% \text { had hypozincemia }(<12.2 \mu \mathrm{M}) \text {, values of nursing home residents significantly lower than free } \\
\text { living }\end{array}$ & {$[117]$} \\
\hline 29,103 subjects, NHANES III & $42.5 \%$ of $\geq 71 \mathrm{y}$. had adequate zinc intake & {$[108]$} \\
\hline 62 healthy, 90-106 y. & $\begin{array}{l}\text { zinc deficiency in } 52 \% \text { male and } 41 \% \text { female subjects, based on a reference range established in } \\
20-64 \mathrm{y} \text {. controls }\end{array}$ & [112] \\
\hline $\begin{array}{l}44 \text { oldest old, } 90-107 \text { y. } \\
44 \text { elderly, } 65-89 \text { y. } \\
44 \text { young, } 20-64 \text { y. }\end{array}$ & serum zinc significantly reduced in oldest old compared to elderly and young & {$[101]$} \\
\hline 50 hospitalized, 83.5 m.a. & $28 \%$ deficient $(<10.7 \mu \mathrm{M}$ serum zinc $)$ & {$[118]$} \\
\hline I3,463 subjects, NHANES II & Correlation between serum zinc and age, decline starts at age 25 & {$[104]$} \\
\hline
\end{tabular}


Table I: Zinc status of the elderly. (Continued)

\begin{tabular}{|c|c|c|}
\hline $\begin{array}{l}10 \text { oldest old, } 93-102 \text { y. } \\
15 \text { old, } 65-80 y . \\
15 \text { young, } 20-40 \text { y. } \\
10 \text { infected, } 63-75 \text { y. }\end{array}$ & $\begin{array}{l}\text { Significantly lower zinc in both groups of older subjects compared to younger ones, no decrease } \\
\text { from old to oldest old } \\
\text { Lowest levels found in infected patients }\end{array}$ & {$[113]$} \\
\hline 101 elderly, 56-83 y. & $35 \%$ zinc deficient $(<90 \mu \mathrm{g} / \mathrm{dL}$ plasma zinc) & [33] \\
\hline $\begin{array}{l}668 \text { hospitalized, } 80.4 \text { m.a. } \\
105 \text { healthy, } 80.9 \text { m.a. }\end{array}$ & $\begin{array}{l}20.2 \% \text { zinc deficient }(<70 \mu \mathrm{g} / \mathrm{dL} \text { (or } 10.7 \mu \mathrm{M} \text { ) serum zinc) in the hospitalized, none in the healthy } \\
\text { controls }\end{array}$ & [120] \\
\hline $\begin{array}{l}188 \text { aged, } 55-70 \text { y. } \\
199 \text { older } 70-85 \text { y. }\end{array}$ & $\begin{array}{l}\text { Erythrocyte zinc lower and urinary zinc higher in the older participants. Less than } 5 \% \text { had } \\
\text { insufficient zinc uptake }(<2 / 3 \text { RDA })\end{array}$ & [103] \\
\hline 93 healthy elderly, 55-70 y. & Average of $13.0 \mu \mathrm{M}$ serum zinc & {$[134,139]$} \\
\hline 67 elderly, 71.7 m.a. & Mean serum zinc $61.8 \mu \mathrm{g} / \mathrm{dL}(=9.4 \mu \mathrm{M}), 76.3 \%$ zinc deficient $(<70 \mu \mathrm{g} / \mathrm{dL}$ or $10.7 \mu \mathrm{M})$ & [114] \\
\hline
\end{tabular}

NHANES: National Health and Nutrition Examination Surveys, RDA: Recommended Daily Allowance, y.: years, m.a.: mean age

These findings have been confirmed by data from the second National Health and Nutrition Examination Survey (NHANES). In its course, over 13,400 serum samples were analyzed for their zinc content. Serum zinc levels increased into the third decade, and declined from there [104]. In combination with an age-dependent decrease of serum zinc, insufficient nutrition and low zinc intake were described, but again mean serum zinc was still in the normal range [105]. In another study, a significant difference between plasma zinc of healthy elderly and a young control group has been found and the average daily intake of healthy elderly was only $60 \%$ of the RDA [106], and even significantly lower in housebound chronically ill (39\% RDA) [107]. This study describes no difference between plasma and whole blood zinc contents between healthy and chronically ill elderly people, but a significant reduction of leukocyte zinc $[106,107]$. The third NHANES has demonstrated in a large study population that inadequate zinc intake is frequent in American elderly [108], and similar observations are reported from other regions of the world, as well. The incidence of zinc deficiency also increases with age in the Japanese [109]. Furthermore, the European Nutrition and Health Report summarizes data regarding the nutritional zinc uptake in elderly from Austria, Denmark, Germany, Hungary, and the UK. Zinc supply decreases with age, although it can be generally regarded as sufficient. Furthermore, there is considerable variation between countries, and zinc uptake is particularly low in UK elderly [110].

Centenarians are a remarkable subgroup of the elderly, who have achieved 'successful aging', without suffering from age-related diseases [111]. Due to its beneficial effect on immunity and healthy aging, measuring the zinc status of these individuals seems indicated to investigate the potential contribution of a difference in zinc homeostasis to the greater health of centenarians. However, it was shown that healthy nonagenarians and centenarians have a high prevalence of zinc deficiency [112]. It still remains to be seen if the decrease of zinc levels reaches a constant level at a certain age, or if the decline continues after the eight decade of life. In one study, measurements showed a reduction in healthy 65-80 year old compared to the zinc status of young adults, but no further reduction in nonagenarians/centenarians [113]. In contrast, a comparison of serum zinc between subjects younger than 65 years, compared to ones aged 65-89 years, and to subjects $\geq 90$ years showed a significant decrease between the oldest old an the other two groups indicating a continuing reduction [101].

These data indicate that improved immune efficiency that promotes successful aging in centenarians is not based on a difference in their zinc status, but act via an unrelated mechanism. This is in accordance with the observation that parameters that are associated with reduced zinc levels, e.g., increased production of pro-inflammatory cytokines, are still observed in centenarians [111].

Whereas it is a general finding that plasma and serum zinc decrease with age, few studies find a high frequency of zinc deficiency in the elderly. In one study, subjects 90 years and older were zinc deficient compared to reference data that the same laboratory had measured in younger individuals [112]. In 67 south African elderly with a mean age of 71.7 years, mean serum concentration was $61.8 \mu \mathrm{g} /$ $\mathrm{dL}$, with $76.3 \%$ of the study population being zinc deficient $(<70 \mu \mathrm{g} / \mathrm{dL})$ [114]. Another group found that only 42.9 percent of the elderly subjects that were investigated had a sufficient intake of zinc ( $>67 \%$ RDA) [115]. However, it has to be noted that in this and several other older studies higher RDAs of $15 \mathrm{mg}$ (male) and $12 \mathrm{mg}$ (female) were used. Even with the current, lower RDAs zinc deficiency would be frequent in the studied population, and 
$30 \%$ were also classified as zinc deficient based on their granulocyte and lymphocyte zinc content. Again, plasma zinc did not indicate zinc deficiency in these subjects, underscoring the difficulties with the use of this parameter [115].

The considerable variability in the classification of elderly people as zinc deficient, either according to their intake or measured zinc status, is caused by more than the use of different RDA, different parameters to measure the zinc status, or the use of different reference values to define zinc deficiency. They can also result from a limited comparability of the populations that are investigated. In addition to regional differences, which affect factors such as food composition, health status and living conditions have great influence. Many studies were performed with healthy elderly. If zinc is as important for immune function as indicated above, this group is the most likely to have normal zinc values. Hence, a difference is likely to exist between apparently healthy, free living elderly and institutionalized subjects, and this has already been described in studies that directly compare these groups $[116,117]$. Accordingly, a high prevalence of zinc deficiency was found in 50 hospitalized elderly patients, $28 \%$ of which were zinc deficient $(<10.7 \mu \mathrm{M}$ plasma zinc) [118], another group of 81 hospitalized subjects (65-102 years) whose mean serum zinc was below $10.7 \mu \mathrm{M}$, and $61 \%$ of which were zinc deficient [119], or in a study where $20.2 \%$ of hospitalized elderly ( $\geq 70 \mathrm{y}$.) had serum zinc below $70 \mu \mathrm{g} / \mathrm{dL}$, while a healthy control group included no zinc deficient subjects [120].

Some authors speculate that insufficient intake or low zinc content in hospital diets may be responsible for the reduced zinc levels found in sick, and especially in hospitalized patients [121]. A negative overall zinc balance in housebound chronically ill patients was documented by a detailed metabolic balance study, in which an average intake of only $39 \%$ of the RDA was found [107]. However, in another study hospitalized elderly had reduced serum and leukocyte zinc levels compared to a free living control group of similar mean age, although their mean dietary intake of zinc did not vary significantly [122].

Independent from the classification of elderly as zinc deficient, correlations between zinc status and immunological parameters have been observed, indicating that even marginal zinc deficiency can affect immunity, while the zinc status is still within the reference values. A study by Bogden and coworkers demonstrates a positive correlation between plasma zinc concentration and delayed cutaneous response to skin antigens [123]. Hereby, even small differences of only $1.5 \mu \mathrm{M}$ seemed to affect skin test anergy. In elderly hemodialysis patients, a correlation between Diphtheria vaccination and zinc status was described. Compared to age-matched controls, the group of patients who did not respond to vaccination had reduced serum zinc levels $(\mathrm{p}<0.004)$, whereas the levels of responders were not significantly decreased [124].

Proliferation and cytokine secretion in response to stimulation with PHA were analyzed in lymphocytes isolated from healthy elderly $(70-85 \mathrm{y}$.) subjects with mean zinc intake and serum and erythrocyte levels within the normal range. There was a positive trend for a correlation between proliferation and serum zinc in male subjects. Furthermore, the production of IL-10 in response to PHA showed a negative correlation with erythrocyte zinc in males, while baseline and PHA-stimulated production of this cytokine were negatively correlated with serum zinc in females [125].

Reduced IL-2 production upon stimulation with PHA was observed in elderly subjects who had reduced levels of cellular zinc in lymphocytes and neutrophils, whereas IL-2 production was not affected in zinc sufficient elderly and younger controls [126]. In another study, subjects 90 years and older were not only zinc deficient, but a positive correlation between serum zinc and percentage of NK cells among leukocytes was established [112]. In a different group of hospitalized patients, serum zinc was negatively correlated to IgG2 levels. Additionally, zinc deficient patients had significantly higher frequencies of congestive cardiopathy, respiratory infections, gastrointestinal diseases, and depression [118].

A decline of zinc status with age has been established, and a correlation between zinc status and immune function in the elderly seems to exist. The question remains if zinc deficiency is caused by infections that occur more frequently in elderly people and lead to a subsequent loss of zinc, or if aging poses a risk of becoming zinc deficient, leading to immunosenescence and increased susceptibility to infectious diseases. In the latter case, zinc supplementation could be a useful approach to improve the immune status of elderly people.

\section{Effect of zinc supplementation on elderly}

Several studies have investigated the impact of zinc supplementation on the immune defense [127], and some of them focused on the investigation of the effect of zinc supplementation on different immune parameters particularly in elderly subjects. Their mean findings are summarized in table 2 . The results are difficult to compare not only due to differences in the studied populations and their zinc status, but also due to study design, the immunological parameters that have been investigated, and dosage, duration, and bioavailability of zinc supplementation. 
Table 2: Zinc supplementation studies in elderly.

\begin{tabular}{|c|c|c|c|c|}
\hline Subjects & Number & Intervention' & Effect & Reference \\
\hline institutionalized $>70$ years & $\begin{array}{l}15(C) \\
15(Z)\end{array}$ & $\begin{array}{l}100 \mathrm{mg} \text { zinc as sulfate } \\
\text { one month }\end{array}$ & $\begin{array}{l}\text { increased } \mathrm{T} \text { cell numbers, } \mathrm{DTH} \text {, and } \\
\text { response to tetanus vaccine compared to } \\
\text { control group }\end{array}$ & {$[130]$} \\
\hline anergic to DTH, 64-76 years & $5(Z)$ & $\begin{array}{l}55 \mathrm{mg} \text { zinc as sulfate } \\
\text { four weeks }\end{array}$ & improved DTH & {$[132]$} \\
\hline free-living, $60-89$ years & $\begin{array}{l}36(P) \\
36(Z, \mid 5) \\
31(Z, 100)\end{array}$ & $\begin{array}{l}15 \text { or } 100 \mathrm{mg} \mathrm{Zn} \text { as acetate } \\
3 \text { months }\end{array}$ & $\begin{array}{l}\text { no effect on DTH or in vitro lymphocyte } \\
\text { proliferation }\end{array}$ & {$[137]$} \\
\hline zinc-deficient males, 65-78 years & $8(Z)$ & $\begin{array}{l}60 \mathrm{mg} \text { zinc } \\
\text { as acetate } \\
4.5 \text { months }\end{array}$ & increase in DTH after supplementation & {$[|3|]$} \\
\hline free-living, 60-89 years & $\begin{array}{l}24(P) \\
20(Z, 15) \\
19(Z, 100)\end{array}$ & $\begin{array}{l}15 \text { or } 100 \mathrm{mg} \mathrm{Zn} \text { as acetate } \\
12 \text { months }\end{array}$ & $\begin{array}{l}\text { negative effect on DTH, NK cell activation } \\
\text { only after } 3 \text { months }\end{array}$ & {$[138]$} \\
\hline institutionalized, 73-106 years & $44(\mathrm{P}) /(\mathrm{Z})$ crossover & $\begin{array}{l}20 \mathrm{mg} \text { zinc } \\
\text { as gluconate } \\
8 \text { weeks }\end{array}$ & increased thymulin activity & {$[136]$} \\
\hline zinc deficient, $50-80$ years & $13(Z)$ & $\begin{array}{l}30 \mathrm{mg} \text { zinc } \\
\text { as gluconate } \\
6 \text { months }\end{array}$ & $\begin{array}{l}\text { increase in plasma thymulin activity, IL-I, and } \\
\text { DTH after supplementation }\end{array}$ & {$[115]$} \\
\hline institutionalized, 64-100 years & $\begin{array}{l}190(C) \\
160(Z)\end{array}$ & $\begin{array}{l}90 \mathrm{mg} \text { zinc as sulfate } \\
60 \text { days }\end{array}$ & $\begin{array}{l}\text { no effect of zinc on response to influenza } \\
\text { vaccination }\end{array}$ & {$[149]$} \\
\hline institutionalized, $\geq 65$ years & $\begin{array}{l}30(P) \\
28(Z)\end{array}$ & $\begin{array}{l}25 \mathrm{mg} \text { zinc } \\
\text { as sulfate } \\
3 \text { months }\end{array}$ & $\begin{array}{l}\text { increase in } C D 4+D R+T \text { cells and cytotoxic } \\
T \text { cells compared to placebo }\end{array}$ & {$[133]$} \\
\hline free-living, 65-82 years & $19(Z)$ & $\begin{array}{l}10 \mathrm{mg} \text { zinc as aspartate } \\
7 \text { weeks }\end{array}$ & $\begin{array}{l}\text { reduced levels of activated } T \text { helper cells and } \\
\text { basal IL- } 6 \text { release from PBMC, improved T } \\
\text { cell response }\end{array}$ & {$[|40| 4 \mid]$,} \\
\hline institutionalized & $\begin{array}{l}25(P) \\
24(Z) \\
6(P) \\
6(Z)\end{array}$ & $\begin{array}{l}45 \mathrm{mg} \text { as gluconate } \\
12 \mathrm{months} \\
45 \mathrm{mg} \text { as gluconate } \\
6 \text { months }\end{array}$ & $\begin{array}{l}\text { reduced incidence of infections } \\
\text { increased IL- } 2 \text { mRNA in response to ex vivo } \\
\text { stimulation with PHA }\end{array}$ & {$[33,128]$} \\
\hline healthy, 55-70 y. & $\begin{array}{l}31(P) \\
28 / 34(Z)\end{array}$ & $\begin{array}{l}15 / 30 \mathrm{mg} \text { zinc as gluconate } \\
6 \text { months }\end{array}$ & $\begin{array}{l}\text { no effect on markers of inflammation or } \\
\text { immunity }\end{array}$ & [134] \\
\hline
\end{tabular}

IThe values are given as elemental zinc

DTH: delayed type hypersensitivity reaction, $(C)$ control group without supplementation, $(P)$ placebo, $(Z)$ zinc supplementation

Several studies find a beneficial effect of zinc on human health. Zinc supplementation (45 mg elemental zinc as gluconate vs. placebo) to a group of elderly significantly reduced the incidence of infections during a one year course [128]. In another group of elderly, supplemented with a mixture of vitamins and minerals including zinc (7 mg per day, given as sulphate) for one year, the incidence of pneumonia was significantly higher in individuals with low $(<70 \mu \mathrm{g} / \mathrm{dL}$, corresponding to $30 \%$ of the study group) serum zinc, compared to ones that were not zinc deficient [129].

Multiple reports describe an effect of zinc on T cells of elderly subjects. In one of the first studies investigating the effect of zinc supplementation on the immune system, healthy subjects over 70 years of age received $220 \mathrm{mg}$ zinc sulfate (corresponding to $50 \mathrm{mg}$ of elemental zinc) twice daily for one month, and were compared to a control 
group that was not supplemented with zinc [130]. Zinc status was not assessed. Whereas the total number of circulating lymphocytes was not affected, the proportion of T cells was significantly increased, but this did not lead to a change of the response to in vitro stimulation with T-cell mitogens. An increased delayed type hypersensitivity (DTH) reaction and response to vaccination with tetanus toxiod was observed [130]. Three further studies confirmed the effect of zinc supplementation on DTH with lower zinc doses, but all were performed with a low number of participants and without a control group $[115,131,132]$. Wagner et al. investigated 5 subjects that were anergic to four different skin test antigens (Candida, Trochophyton, mumps, tuberculin), and all five tested positive to at least one antigen after 4 weeks of supplementation with $55 \mathrm{mg}$ zinc (as sulfate) per day [132]. Cossack found in eight zinc deficient elderly males, who were classified as anergic to skin antigen tests, an improvement of DTH after supplementation with $60 \mathrm{mg}$ per day. This was accompanied by an increase of plasma and cellular zinc [131]. Prasad and coworkers investigated 13 zinc deficient subjects whose plasma zinc levels and granulocyte and lymphocyte content increased significantly after supplementation with $30 \mathrm{mg}$ zinc per day. They also found an increase in the number of positive skin test reactions after six months [115]. However, as no control groups have been investigated in either study, it can not be excluded that repeated testing may have contributed to the improvement in DTH reactions.

A beneficial effect of zinc on T cell function has also been observed when other parameters were investigated. A significant increase in the numbers of cytotoxic T cells and activated (HLA-DR positive) $\mathrm{T}$ helper cells was found in residents of a retirement home who had been supplemented with zinc (25 mg per day) [133]. This raise in HLA-DR positive cells seems to result from increased total $\mathrm{T}$ cell numbers, while the percentage of activated cells within the T cell population remains constant $[133,134]$. Fabris et al. have found decreased plasma zinc with age and an age-dependent decrease of plasma thymulin activity. Because thymulin activity was restored by in vitro addition of zinc, the effect was not caused by thymic involution, rather was thymulin inactive due to decreased plasma zinc [135]. This observation has been confirmed in a later study with 44 institutionalized elderly, also detecting a partial recovery of thymulin activity after in vitro zinc supplementation. In the same study, a 16 week crossover with 8 weeks of zinc supplementation $(20 \mathrm{mg} /$ day) and 8 weeks of placebo caused an increase in serum levels of active thymulin, but the effect was only significant in lean subjects with a body mass index $\leq 21$ [136]. In another in vivo study with zinc deficient elderly subjects, zinc supplementation also significantly increased serum thymulin activity [115].
The results showing an improvement of T cell-dependent reactions after zinc supplementation are not unchallenged. In a well designed study, Bogden and coworkers supplemented elderly subjects with zinc in three groups: placebo, $15 \mathrm{mg}$ zinc per day, and $100 \mathrm{mg}$ zinc per day. To prevent underlying effects of deficiencies in other micronutrients, multivitamins and mineral supplements were given to all participants. Baseline data at the beginning of the study [123] as well as results after three months [137] and after one year were reported [138]. After three months, no significant effects were found in response to either dose of zinc, neither on DTH, nor lymphocyte proliferation to several antigens. Initially, zinc supplementation in subjects who are not zinc deficient may be beneficial, but the effect could be only temporary, due to adaptation to a higher zinc intake [137]. This assumption is supported by the observation that NK cell activity increased transiently after 3 months in the group receiving $100 \mathrm{mg}$ zinc, but not after 6 or 12 months. After one year, an increase in DTH was observed in all three groups. This may have been caused by repeated testing, as discussed above, or by a booster effect of the additional multivitamin and mineral supplement that had been administered to all participants. However, zinc supplementation in both groups significantly diminished this effect. The difference between this study and the ones discussed above could be due to the fact that this is the only one that used a placebo group for comparison, or that zinc may interfere with the beneficial effect of one of the other micronutrients, or be a sign of adaptation to zinc supplementation during the longer supplementation period. It has also to be considered that no zinc deficiency was observed in these subjects, which had a mean of approximately $13 \mu \mathrm{M}$ plasma zinc [138].

A six month, placebo controlled supplementation study with 15 and $30 \mathrm{mg} \mathrm{Zn}$ per day (as gluconate) investigated the long-term effects on the immune status of 93 healthy Irish individuals between 55 and 70 years [139]. At baseline, positive correlations between erythrocyte zinc and the amount of T lymphocytes (CD3+), NKT cells (CD3+/ CD16+/CD56+), activated T cells (CD25+ HLA-DR+), and naïve $\mathrm{T}$ cells (CD3+/CD45RA+) were observed. In addition, erythrocyte zinc was inversely correlated with granulocyte phagocytic capacity and serum zinc with the concentration of CRP [134]. After receiving zinc, the participants supplemented with $15 \mathrm{mg} \mathrm{Zn} /$ day had an increased ratio of helper to cyctotoxic T cells, and after 3 months B cell numbers were lower in the $30 \mathrm{mg}$ group compared to the other two groups. Zinc supplementation had no impact on a vast number of other parameters investigated, including inflammation markers, granulocyte phagocytosis, and cytokine production by monocytes. The population investigated in this study had mean serum zinc of $13 \mu \mathrm{M}$ and thus no zinc deficiency at the 
beginning of the study, which may explain the lack of significant long-term effects of zinc supplementation on most immune parameters $[134,139]$.

Zinc supplementation does not just promote the immune response; it rather normalizes immune function on the cellular level. Compared to younger subjects, PBMC from elderly have increased ex vivo generation of pro-inflammatory cytokines, and normalized cytokine production was observed after zinc supplementation $[128,140]$. In addition, zinc supplementation improves T cell function, causing reduced levels of unspecifically activated T cells [141], and improved IL-2 mRNA expression and T cell response to stimulation with mitogens $[128,140]$. This does not indicate, however, that an effect of zinc supplementation on cytokine production is limited to the elderly. Zinc supplementation to younger subjects (19-31 years of age, 15 mg Zn per day as $\mathrm{ZnSO}_{4}$ ), resulted in increased mRNA production of TNF- $\alpha$ and IL- $1 \beta$ in LPS-treated monocytes and granulocytes, and augmented IFN- $\gamma$ mRNA in T cells treated with microbeads to simulate antigen presentation [142].

The intake of zinc was positively correlated with the results of tests for cognitive performance in 260 subjects between 65 and 90 years [143]. Another study reported a negative correlation between zinc status and indicators for stress and depression and a positive correlation with the mental capacity in elderly from different European countries [144], but this was not confirmed in an investigation of 387 participants between 55 and 87 years who had been supplemented either with placebo, 15 , or $30 \mathrm{mg}$ elemental zinc per day (as gluconate) for 6 months [145]. Here, despite significant changes in serum zinc, almost no significant associations between zinc status at baseline and eight measures of cognitive performance were found. In response to supplementation, only two statistically significant effects were observed, namely a temporary improvement of spatial working memory and an impairment of attention [145].

On the other hand, another recent study with 97 healthy elderly from Italy, Greece, and Poland found slight beneficial effects of zinc supplementation on cognitive performance, measured by the Mini Mental State examination, and mood conditions, measured by the geriatric depression scale. Furthermore, it demonstrated an improvement on the perceived stress scale. Notably, this latter effect of zinc supplementation was more pronounced in subjects with a certain polymorphism in the promoter region of the gene for IL-6 [146].

Inflammatory cytokines have been suggested to affect cognitive performance via the production of reactive oxygen species in brain ageing [147]. Chronic low level inflam- mation is common in the elderly, and zinc deficiency impairs cytokine homeostasis in this population, leading to increased production of pro-inflammatory cytokines such as IL-6, which can be corrected by zinc supplementation $[70,140]$. Taken together, these data suggest that a supplementation with zinc could act on cognitive and psychological parameters via modulation pro-inflammatory cytokine levels, although more data to confirm this hypothesis are certainly required.

Other studies investigated zinc supplementation in combination with additional micronutrients. In a larger study, 725 institutionalized patients (65-103 years) were supplemented for 2 years with zinc sulfate $(20 \mathrm{mg}$ zinc) together with selenium sulfide (100 $\mu$ g selenium), or multivitamins, or a combination of both [148]. Patients treated with selenium and zinc either alone or together with vitamins, showed higher antibody titers after influenza vaccination, whereas vitamins alone had a negative effect on response to vaccination. An improvement of influenza vaccination response by zinc was not confirmed in another study in which zinc was administered together with arginine [149], but the relatively high dose of zinc used in this case (zinc sulfate, $400 \mathrm{mg}$ per day $=90 \mathrm{mg}$ elemental zinc) might have suppressed T cell help.

Although supplementation together with other micronutrients makes it difficult to specify the contribution of zinc, this is possible if appropriate controls are included. The example of a recent study in Mexican children clearly demonstrates an effect of zinc supplementation on several parameters of immune function even if it was administered in the presence of other micronutrients [150].

Zinc is generally regarded as a non-toxic essential metal. Accordingly, correction of zinc deficiency in the elderly should generally improve the performance of the immune system, but overdosing zinc supplementation can also have a negative impact on immune efficiency. In this respect, two effects are relevant. On the one hand, zinc can interfere with the uptake of copper. Hence, long-term high-dose zinc supplementation can lead to severe anemia and neutropenia, based on copper deficiency [151]. On the other hand, pharmacological doses of zinc suppress $\mathrm{T}$ cell-dependent immune responses [51], and may cause a temporary reduction of B cell counts [134], leading to an impaired adaptive immune response when too much zinc is supplemented.

\section{Conclusion}

Zinc ions are indispensable for immune function, especially for $\mathrm{T}$ cell mediated events, which are primarily affected in immunosenescence. The high prevalence of zinc deficiency in hospitalized subjects and the correlation between zinc status and immune function surely jus- 
tifies zinc supplementation to these patients to normalize zinc levels, and hereby restore important functions of the immune system. One central question remains: Should the decrease of zinc status with age be seen as a marginal zinc deficiency, which, in combination with multiple other factors, increases the susceptibility for infectious diseases and cancer, and should zinc be given to those with no clinical symptoms? From the results published so far, it looks like a moderate zinc supplementation that stays well below the limits for adverse effects could have substantial benefits. However, a rapid and reliable method for the assessment of zinc status would be helpful to identify those who would benefit most from zinc supplementation.

\section{Competing interests}

The authors declare that they have no competing interests.

\section{Authors' contributions}

$\mathrm{HH}$ and LR have written the manuscript.

\section{References}

I. Vallee BL, Falchuk KH: The biochemical basis of zinc physiology. Physiol Rev 1993, 73:79-118.

2. Andreini C, Banci L, Bertini I, Rosato A: Counting the zinc-proteins encoded in the human genome. J Proteome Res 2006 5:196-201.

3. Ibs KH, Rink L: Zinc-altered immune function. J Nutr 2003, I33:1452S-1456S.

4. McClain C), McClain M, Barve S, Boosalis MG: Trace metals and the elderly. Clin Geriatr Med 2002, I 8:80I-8I8.

5. Cousins RJ, Liuzzi JP, Lichten LA: Mammalian zinc transport, trafficking, and signals. J Biol Chem 2006, 28 I:24085-24089.

6. Rink L, Haase H: Zinc homeostasis and immunity. Trends Immunol 2007, 28: I-4.

7. Truong-Tran AQ, Carter J, Ruffin RE, Zalewski PD: The role of zinc in caspase activation and apoptotic cell death. Biometals 200I, 14:315-330.

8. Liuzzi JP, Cousins RJ: Mammalian zinc transporters. Annu Rev Nutr 2004, 24: 15I-172.

9. Liuzzi JP, Lichten LA, Rivera S, Blanchard RK, Aydemir TB, Knutson MD, Ganz T, Cousins RJ: Interleukin-6 regulates the zinc transporter Zip 14 in liver and contributes to the hypozincemia of the acute-phase response. Proc Natl Acad Sci USA 2005, 1 02:6843-6848.

10. Beisel WR: Single nutrients and immunity. Am J Clin Nutr 1982, 35:417-468.

II. Neldner $\mathrm{KH}$, Hambidge KM: Zinc therapy of acrodermatitis enteropathica. N Engl J Med 1975, 292:879-882.

12. Kury S, Dreno B, Bezieau S, Giraudet S, Kharfi M, Kamoun R, Moisan JP: Identification of SLC39A4, a gene involved in acrodermatitis enteropathica. Nat Genet 2002, 3 I:239-240.

13. Wang K, Zhou B, Kuo YM, Zemansky J, Gitschier J: A novel member of a zinc transporter family is defective in acrodermatitis enteropathica. Am J Hum Genet 2002, 7 I:66-73.

14. Cousins RJ, Blanchard RK, Popp MP, Liu L, Cao J, Moore JB, Green $C L$ : A global view of the selectivity of zinc deprivation and excess on genes expressed in human THP-I mononuclear cells. Proc Natl Acad Sci USA 2003, 100:6952-6957.

15. Haase H, Mazzatti DJ, White A, Ibs KH, Engelhardt G, Hebel S, Powell $J R$, Rink L: Differential gene expression after zinc supplementation and deprivation in human leukocyte subsets. Mol Med 2007, 1 3:362-370.

16. Fraker PJ, King LE: Reprogramming of the immune system during zinc deficiency. Annu Rev Nutr 2004, 24:277-298.

17. Beach RS, Gershwin ME, Hurley LS: Gestational zinc deprivation in mice: persistence of immunodeficiency for three generations. Science 1982, 218:469-47I.
18. Wellenreuther G, Cianci M, Tucoulou R, Meyer-Klaucke W, Haase H: The ligand environment of zinc stored in vesicles. Biochem Biophys Res Commun 2009, 380: 198-203.

19. Maret W: Molecular aspects of human cellular zinc homeostasis: redox control of zinc potentials and zinc signals. Biometals 2009, 22: 149-157.

20. Haase H, Rink L: Functional Significance of Zinc-Related Signaling Pathways in Immune Cells. Annu Rev Nutr 2009 in press.

21. Csermely P, Somogyi J: Zinc as a possible mediator of signal transduction in T lymphocytes. Acta Physiol Hung 1989, 74:195-199.

22. Huse M, Eck MJ, Harrison SC: A Zn2+ ion links the cytoplasmic tail of CD4 and the N-terminal region of Lck. J Biol Chem 1998, 273:18729-18733.

23. Kim PW, Sun ZY, Blacklow SC, Wagner G, Eck MJ: A zinc clasp structure tethers Lck to $T$ cell coreceptors CD4 and CD8. Science 2003, 30 I: 1725-1728.

24. Lin RS, Rodriguez C, Veillette A, Lodish HF: Zinc is essential for binding of p56(lck) to CD4 and CD8alpha. J Biol Chem 1998, 273:32878-32882.

25. Romir J, Lilie H, Egerer-Sieber C, Bauer F, Sticht H, Muller YA: Crystal structure analysis and solution studies of human Lck-SH3; zinc-induced homodimerization competes with the binding of proline-rich motifs. J Mol Biol 2007, 365:14|7-I428.

26. Haase $H$, Ober-Blobaum JL, Engelhardt $G$, Hebel S, Heit A, Heine $H$, Rink L: Zinc signals are essential for lipopolysaccharideinduced signal transduction in monocytes. J Immunol 2008, | 81:649|-6502.

27. von Bulow V, Rink L, Haase H: Zinc-mediated inhibition of cyclic nucleotide phosphodiesterase activity and expression suppresses TNF-alpha and IL-I beta production in monocytes by elevation of guanosine 3',5'-cyclic monophosphate. J Immunol 2005, 175:4697-4705.

28. von Bulow V, Dubben S, Engelhardt G, Hebel S, Plumakers B, Heine $H$, Rink $L$, Haase $H$ : Zinc-dependent suppression of TNF-alpha production is mediated by protein kinase A-induced inhibition of Raf-I, I kappa B kinase beta, and NF-kappa B. J Immunol 2007, I79:4180-4186.

29. Taylor KM, Vichova P, Jordan N, Hiscox S, Hendley R, Nicholson RI: ZIP7-mediated intracellular zinc transport contributes to aberrant growth factor signaling in antihormone-resistant breast cancer Cells. Endocrinology 2008, 149:4912-4920.

30. Aydemir TB, Liuzzi JP, McClellan S, Cousins RJ: Zinc transporter ZIP8 (SLC39A8) and zinc influence IFN- $\{$ gamma $\}$ expression in activated human T cells. I Leukoc Biol 2009 in press.

31. Laity JH, Andrews GK: Understanding the mechanisms of zincsensing by metal-response element binding transcription factor-I (MTF-I). Arch Biochem Biophys 2007, 463:20I-2I0.

32. Lichten LA, Cousins RJ: Mammalian Zinc Transporters: Nutritional and Physiologic Regulation. Annu Rev Nutr 2009 in press.

33. Prasad AS, Bao B, Beck FW, Sarkar FH: Correction of interleukin2 gene expression by in vitro zinc addition to mononuclear cells from zinc-deficient human subjects: a specific test for zinc deficiency in humans. Transl Res 2006, 148:325-333.

34. Hujanen ES, Seppa ST, Virtanen K: Polymorphonuclear leukocyte chemotaxis induced by zinc, copper and nickel in vitro. Biochim Biophys Acta 1995, I 245: I45-152.

35. Chavakis T, May AE, Preissner KT, Kanse SM: Molecular mechanisms of zinc-dependent leukocyte adhesion involving the urokinase receptor and beta2-integrins. Blood 1999, 93:2976-2983.

36. Keen CL, Gershwin ME: Zinc deficiency and immune function. Annu Rev Nutr 1990, 10:415-431.

37. Wirth J], Fraker PJ, Kierszenbaum F: Zinc requirement for macrophage function: effect of zinc deficiency on uptake and killing of a protozoan parasite. Immunology 1989, 68:1 I4-119.

38. Allen JI, Perri RT, McClain CJ, Kay NE: Alterations in human natural killer cell activity and monocyte cytotoxicity induced by zinc deficiency. J Lab Clin Med 1983, I 02:577-589.

39. Rajagopalan S, Winter CC, Wagtmann N, Long EO: The Ig-related killer cell inhibitory receptor binds zinc and requires zinc for recognition of HLA-C on target cells. J Immunol 1995, | 55:4|43-4|46.

40. Prasad AS: Effects of zinc deficiency on ThI and Th2 cytokine shifts. J Infect Dis 2000, I 82(Suppl I):S62-S68. 
41. Flynn A: Control of in vitro lymphocyte proliferation by copper, magnesium and zinc deficiency. I Nutr 1984, I I 4:2034-2042.

42. Zanzonico P, Fernandes G, Good RA: The differential sensitivity of T-cell and B-cell mitogenesis to in vitro zinc deficiency. Cell Immunol I98I, 60:203-2II.

43. Iwata T, Incefy GS, Tanaka T, Fernandes G, Menendez-Botet CJ, Pih K, Good RA: Circulating thymic hormone levels in zinc deficiency. Cell Immunol 1979, 47:100-105.

44. Dardenne M, Savino W, Wade S, Kaiserlian D, Lemonnier D, Bach JF: In vivo and in vitro studies of thymulin in marginally zincdeficient mice. Eur J Immunol I984, 14:454-458.

45. Prasad AS, Meftah S, Abdallah J, Kaplan J, Brewer GJ, Bach JF Dardenne M: Serum thymulin in human zinc deficiency. J Clin Invest 1988, 82: |202-1210.

46. Bao B, Prasad AS, Beck FW, Godmere M: Zinc modulates mRNA levels of cytokines. Am J Physiol Endocrinol Metab 2003, 285:EI095-EII02.

47. Beck FW, Prasad AS, Kaplan J, Fitzgerald JT, Brewer GJ: Changes in cytokine production and $\mathrm{T}$ cell subpopulations in experimentally induced zinc-deficient humans. Am J Physiol 1997, 272:EI002-EI007.

48. Prasad AS, Beck FW, Grabowski SM, Kaplan J, Mathog RH: Zinc deficiency: changes in cytokine production and T-cell subpopulations in patients with head and neck cancer and in noncancer subjects. Proc Assoc Am Physicians 1997, 109:68-77.

49. Wellinghausen N, Martin M, Rink L: Zinc inhibits interleukin-Idependent T cell stimulation. Eur I Immunol 1997, 27:2529-2535.

50. aCampo, Wellinghausen N, Faber C, Fischer A, Rink L: Zinc inhibits the mixed lymphocyte culture. Biol Trace Elem Res 200I, 79:15-22.

5I. Faber C, Gabriel P, lbs KH, Rink L: Zinc in pharmacological doses suppresses allogeneic reaction without affecting the antigenic response. Bone Marrow Transplant 2004, 33:1241-1246.

52. Wellinghausen $N$, Kirchner $H$, Rink L: The immunobiology of zinc. Immunol Today 1997, | 8:519-521.

53. Zhou Z, Wang L, Song Z, Saari JT, McClain CJ, Kang YJ: Abrogation of nuclear factor-kappaB activation is involved in zinc inhibition of lipopolysaccharide-induced tumor necrosis factoralpha production and liver injury. Am J Pathol 2004 164:1547-1556.

54. Roberts-Thomson IC, Whittingham S, Youngchaiyud U, Mackay IR: Ageing, immune response, and mortality. Lancet 1974 2:368-370

55. Haase $\mathrm{H}$, Mocchegiani E, Rink L: Correlation between zinc status and immune function in the elderly. Biogerontology 2006, 7:421-428.

56. Dardenne M: Zinc and immune function. Eur / Clin Nutr 2002, 56:S20-S23.

57. Plouffe JF, Breiman RF, Facklam RR: Bacteremia with Streptococcus pneumoniae. Implications for therapy and prevention. Franklin County Pneumonia Study Group. JAMA 1996, 275: $194-198$.

58. Davies PD: Tuberculosis in the elderly. J Antimicrob Chemother 1994, 34:93-100

59. Donahue JG, Choo PW, Manson JE, Platt R: The incidence of herpes zoster. Arch Intern Med 1995, I 55:1605-1609.

60. Mariotti S, Sansoni P, Barbesino G, Caturegli P, Monti D, Cossarizza A, Giacomelli T, Passeri G, Fagiolo U, Pinchera A: Thyroid and other organ-specific autoantibodies in healthy centenarians. Lancet 1992, 339: 1506-1508.

61. Steinmann G, Hartwig M: Immunology of centenarians. Immunol Today 1995, 16:549-550.

62. Nakazawa T, Houjyo S, Dobashi K, Sato K: Influence of aging and sex on specific IgE antibody production. Intern Med 1994 33:396-40I.

63. Schwarzenbach HR, Nakagawa T, Conroy MC, de Weck AL: Skin reactivity, basophil degranulation and IgE levels in ageing. Clin Allergy 1982, I 2:465-473.

64. Yancik R: Cancer burden in the aged: an epidemiologic and demographic overview. Cancer 1997, 80:1273-1283.

65. Ibs KH, Rink L: [The immune system in aging]. $Z$ Gerontol Geriatr 200I, 34:480-485

66. Rink L, Seyfarth $M$ : [Characteristics of immunologic test values in the elderly]. Z Gerontol Geriatr 1997, 30:220-225.
67. Schroder AK, Rink L: Neutrophil immunity of the elderly. Mech Ageing Dev 2003, 124:419-425.

68. Gardner ID, Lim ST, Lawton JW: Monocyte function in ageing humans. Mech Ageing Dev 198I, 16:233-239.

69. Rich EA, Mincek MA, Armitage KB, Duffy EG, Owen DC, Fayen JD, Hom DL, Ellner J]: Accessory function and properties of monocytes from healthy elderly humans for $T$ lymphocyte responses to mitogen and antigen. Gerontology 1993, 39:93-108.

70. Mariani E, Cattini L, Neri S, Malavolta M, Mocchegiani E, Ravaglia G, Facchini A: Simultaneous evaluation of circulating chemokine and cytokine profiles in elderly subjects by multiplex technology: relationship with zinc status. Biogerontology 2006, 7:449-459.

7I. Fagiolo U, Cossarizza A, Scala E, Fanales-Belasio E, Ortolani C, Cozzi E, Monti D, Franceschi C, Paganelli R: Increased cytokine production in mononuclear cells of healthy elderly people. Eur J Immunol 1993, 23:2375-2378.

72. Gabriel P, Cakman I, Rink L: Overproduction of monokines by leukocytes after stimulation with lipopolysaccharide in the elderly. Exp Gerontol 2002, 37:235-247.

73. Cakman I, Kirchner H, Rink L: Zinc supplementation reconstitutes the production of interferon-alpha by leukocytes from elderly persons. J Interferon Cytokine Res 1997, 17:469-472.

74. Pietschmann P, Hahn P, Kudlacek S, Thomas R, Peterlik M: Surface markers and transendothelial migration of dendritic cells from elderly subjects. Exp Gerontol 2000, 35:213-224.

75. Facchini A, Mariani E, Mariani AR, Papa S, Vitale M, Manzoli FA: Increased number of circulating Leu I I+ (CD I6) large granular lymphocytes and decreased NK activity during human ageing. Clin Exp Immunol 1987, 68:340-347.

76. Solana R, Alonso MC, Pena J: Natural killer cells in healthy aging. Exp Gerontol 1999, 34:435-443.

77. Solana R, Mariani $E:$ NK and NK/T cells in human senescence. Vaccine 2000, 18:1613-1620.

78. Borrego F, Alonso MC, Galiani MD, Carracedo J, Ramirez R, Ostos B Pena J, Solana R: NK phenotypic markers and IL2 response in NK cells from elderly people. Exp Gerontol 1999, 34:253-265.

79. Paganelli R, Quinti I, Fagiolo U, Cossarizza A, Ortolani C, Guerra E, Sansoni P, Pucillo LP, Scala E, Cozzi E: Changes in circulating B cells and immunoglobulin classes and subclasses in a healthy aged population. Clin Exp Immunol 1992, 90:35I-354.

80. Weksler ME, Szabo P: The effect of age on the B-cell repertoire. J Clin Immunol 2000, 20:240-249.

81. Pawelec G, Remarque E, Barnett $Y$, Solana R: T cells and aging. Front Biosci 1998, 3:d59-d99.

82. McLeod JD: Apoptotic capability in ageing $\mathbf{T}$ cells. Mech Ageing Dev 2000, I21:151-159.

83. Mitchell WA, Meng I, Nicholson SA, Aspinall R: Thymic output, ageing and zinc. Biogerontology 2006, 7:46|-470.

84. Taub DD, Longo DL: Insights into thymic aging and regeneration. Immunol Rev 2005, 205:72-93.

85. Sbarbati A, Mocchegiani E, Marzola P, Tibaldi A, Mannucci R, Nicolato E, Osculati F: Effect of dietary supplementation with zinc sulphate on the aging process: a study using high field intensity MRI and chemical shift imaging. Biomed Pharmacother 1998, 52:454-458.

86. Dardenne M, Boukaiba N, Gagnerault MC, Homo-Delarche F, Chappuis $P$, Lemonnier $D$, Savino $W$ : Restoration of the thymus in aging mice by in vivo zinc supplementation. Clin Immunol Immunopathol 1993, 66:127-135.

87. Posnett DN, Sinha R, Kabak S, Russo C: Clonal populations of $\mathbf{T}$ cells in normal elderly humans: the $\mathbf{T}$ cell equivalent to "benign monoclonal gammapathy". J Exp Med 1994, 179:609-618.

88. Uciechowski P, Kahmann L, Plumakers B, Malavolta M, Mocchegiani E, Dedoussis G, Herbein G, Jajte J, Fulop T, Rink L: THI and TH2 cell polarization increases with aging and is modulated by zinc supplementation. Exp Gerontol 2008, 43:493-498.

89. Cakman I, Rohwer J, Schutz RM, Kirchner H, Rink L: Dysregulation between THI and TH2 T cell subpopulations in the elderly. Mech Ageing Dev 1996, 87: 197-209.

90. Paganelli R, Scala E, Quinti I, Ansotegui II: Humoral immunity in aging. Aging (Milano) 1994, 6: I43-150.

91. Rink L, Cakman I, Kirchner H: Altered cytokine production in the elderly. Mech Ageing Dev 1998, 102:199-209. 
92. Driessen C, Hirv K, Rink L, Kirchner H: Induction of cytokines by zinc ions in human peripheral blood mononuclear cells and separated monocytes. Lymphokine Cytokine Res 1994, I3: I 5-20.

93. Metz $\mathrm{CH}$, Schroder AK, Overbeck S, Kahmann L, Plumakers B, Rink $\mathrm{L}$ : T-helper type I cytokine release is enhanced by in vitro zinc supplementation due to increased natural killer cells. Nutrition 2007, 23:157-163.

94. Berg K, Bolt G, Andersen H, Owen TC: Zinc potentiates the antiviral action of human IFN-alpha tenfold. J Interferon Cytokine Res 200I, 2 I:47I -474.

95. Bogden JD, Louria DB: Diet and human immune function Edited by: Hughes DA, Darlington LG, Bendich A. Humana Press Inc., Totowa, NJ; 2004:79-I0I

96. Sandstead HH, Henriksen LK, Greger JL, Prasad AS, Good RA: Zinc nutriture in the elderly in relation to taste acuity, immune response, and wound healing. Am J Clin Nutr 1982, 36: I 046-1059.

97. Jansen J, Karges W, Rink L: Zinc and Diabetes - clinical links and molecular mechanisms. I Nutr Biochem 2009, 20:399-4I 7.

98. Maret $\mathrm{W}$, Sandstead $\mathrm{HH}$ : Zinc requirements and the risks and benefits of zinc supplementation. J Trace Elem Med Biol 2006, 20:3-18.

99. Haase H, Hebel S, Engelhardt G, Rink L: Flow cytometric measurement of labile zinc in peripheral blood mononuclear cells. Anal Biochem 2006, 352:222-230.

100. Lindeman RD, Clark ML, Colmore JP: Influence of age and sex on plasma and red-cell zinc concentrations. J Gerontol 1971, 26:358-363.

I0I. Ravaglia G, Forti P, Maioli F, Nesi B, Pratelli L, Savarino L, Cucinotta $D$, Cavalli G: Blood micronutrient and thyroid hormone concentrations in the oldest-old. J Clin Endocrinol Metab 2000, 85:2260-2265.

102. Vir SC, Love AH: Zinc and copper status of the elderly. Am J Clin Nutr 1979, 32: |472-I476.

103. Andriollo-Sanchez M, Hininger-Favier I, Meunier N, Toti E, Zaccaria M, Brandolini-Bunlon M, Polito A, O'Connor JM, Ferry M, Coudray C, Roussel AM: Zinc intake and status in middle-aged and older European subjects: the ZENITH study. Eur J Clin Nutr 2005 , 59(Suppl 2):S37-S4I

104. Hotz C, Peerson JM, Brown KH: Suggested lower cutoffs of serum zinc concentrations for assessing zinc status: reanalysis of the second National Health and Nutrition Examination Survey data (1 976-I 980). Am J Clin Nutr 2003, 78:756-764.

105. Swanson CA, Mansourian R, Dirren $\mathrm{H}$, Rapin $\mathrm{CH}$ : Zinc status of healthy elderly adults: response to supplementation. Am J Clin Nutr 1988, 48:343-349.

106. Bunker VW, Hinks LJ, Lawson MS, Clayton BE: Assessment of zinc and copper status of healthy elderly people using metabolic balance studies and measurement of leucocyte concentrations. Am J Clin Nutr 1984, 40:1096-I I02.

107. Bunker VW, Hinks LJ, Stansfield MF, Lawson MS, Clayton BE: Metabolic balance studies for zinc and copper in housebound elderly people and the relationship between zinc balance and leukocyte zinc concentrations. Am / Clin Nutr 1987, 46:353-359.

108. Briefel RR, Bialostosky K, Kennedy-Stephenson J, McDowell MA, Ervin RB, Wright JD: Zinc intake of the U.S. population: findings from the third National Health and Nutrition Examination Survey, I 988-1994. J Nutr 2000, 130:1367S-I373S.

109. Kogirima M, Kurasawa R, Kubori S, Sarukura N, Nakamori M, Okada $\mathrm{S}$, Kamioka $\mathrm{H}$, Yamamoto S: Ratio of low serum zinc levels in elderly Japanese people living in the central part of Japan. Eur J Clin Nutr 2007, 61:375-381.

I I0. Fabian E, Elmadfa I: Nutritional situation of the elderly in the European Union: data of the European Nutrition and Health Report (2004). Ann Nutr Metab 2008, 52:57-6I.

III. Franceschi C, Monti D, Sansoni P, Cossarizza A: The immunology of exceptional individuals: the lesson of centenarians. Immunol Today 1995, 16:12-16.

I 12. Ravaglia G, Forti P, Maioli F, Bastagli L, Facchini A, Mariani E, Savarino L, Sassi S, Cucinotta D, Lenaz G: Effect of micronutrient status on natural killer cell immune function in healthy free-living subjects aged $>I=90$ y. Am J Clin Nutr 2000, 7 I:590-598.

I 13. Mocchegiani E, Muzzioli M, Giacconi R, Cipriano C, Gasparini N, Franceschi C, Gaetti R, Cavalieri E, Suzuki H: Metallothioneins/ PARP-I/IL-6 interplay on natural killer cell activity in elderly: parallelism with nonagenarians and old infected humans. Effect of zinc supply. Mech Ageing Dev 2003, I 24:459-468.
II4. Oldewage-Theron WH, Samuel FO, Venter CS: Zinc deficiency among the elderly attending a care centre in Sharpeville, South Africa. J Hum Nutr Diet 2008, 2 I:566-574.

I 15. Prasad AS, Fitzgerald JT, Hess JW, Kaplan J, Pelen F, Dardenne M: Zinc deficiency in elderly patients. Nutrition 1993, 9:2 I 8-224.

I 16. Goode HF, Penn ND, Kelleher J, Walker BE: Evidence of cellular zinc depletion in hospitalized but not in healthy elderly subjects. Age Ageing 1991, 20:345-348.

II7. Worwag M, Classen HG, Schumacher E: Prevalence of magnesium and zinc deficiencies in nursing home residents in Germany. Magnes Res 1999, I 2:181-189.

I 8. Pepersack T, Rotsaert P, Benoit F, Willems D, Fuss M, Bourdoux P, Duchateau J: Prevalence of zinc deficiency and its clinical relevance among hospitalised elderly. Arch Gerontol Geriatr 2001, 33:243-253.

119. Girodon F, Blache D, Monget AL, Lombart M, Brunet-Lecompte P, Arnaud J, Richard MJ, Galan P: Effect of a two-year supplementation with low doses of antioxidant vitamins and/or minerals in elderly subjects on levels of nutrients and antioxidant defense parameters. J Am Coll Nutr 1997, 16:357-365.

120. Belbraouet S, Biaudet H, Tebi A, Chau N, Gray-Donald K, Debry G: Serum zinc and copper status in hospitalized vs. healthy elderly subjects. I Am Coll Nutr 2007, 26:650-654

I2I. Senapati A, Jenner G, Thompson RP: Zinc in the elderly. $Q$ J Med 1989, 70:81-87.

122. Stafford W, Smith RG, Lewis SJ, Henery E, Stephen PJ, Rafferty J, Simpson GK, Bell PC, O'Rorke K: A study of zinc status of elderly institutionalized patients. Age Ageing 1988, I 7:42-48.

123. Bogden JD, Oleske JM, Munves EM, Lavenhar MA, Bruening KS, Kemp FW, Holding KJ, Denny TN, Louria DB: Zinc and immunocompetence in the elderly: baseline data on zinc nutriture and immunity in unsupplemented subjects. Am J Clin Nutr 1987, 46:101-109.

124. Kreft B, Fischer A, Kruger S, Sack K, Kirchner H, Rink L: The impaired immune response to diphtheria vaccination in elderly chronic hemodialysis patients is related to zinc deficiency. Biogerontology 2000, I:6I-66.

125. Finamore A, Devirgiliis C, Panno D, D'Aquino M, Polito A, Venneria $E$, Raguzzini $A$, Coudray $C$, Mengheri $E$ : Immune response in relation to zinc status, sex and antioxidant defence in Italian elderly population: the ZENITH study. Eur J Clin Nutr 2005, 59(Suppl 2):S68-S72.

126. Kaplan J, Hess JW, Prasad AS: Impaired interleukin-2 production in the elderly: Association with mild zinc deficiency. J Trace Elem Exp Med 1988, I:3-8.

127. Overbeck S, Rink L, Haase $\mathrm{H}$ : Modulating the immune response by oral zinc supplementation: a single approach for multiple diseases. Arch Immunol Ther Exp (Warsz) 2008, 56: I 5-30.

128. Prasad AS, Beck FW, Bao B, Fitzgerald JT, Snell DC, Steinberg JD, Cardozo LI: Zinc supplementation decreases incidence of infections in the elderly: effect of zinc on generation of cytokines and oxidative stress. Am J Clin Nutr 2007, 85:837-844.

129. Meydani SN, Barnett JB, Dallal GE, Fine BC, Jacques PF, Leka LS, Hamer DH: Serum zinc and pneumonia in nursing home elderly. Am J Clin Nutr 2007, 86: I I67-I I73.

130. Duchateau J, Delepesse G, Vrijens R, Collet H: Beneficial effects of oral zinc supplementation on the immune response of old people. Am J Med 1981, 70:1001-1004.

|3|. Cossack ZT: T-lymphocyte dysfunction in the elderly associated with zinc deficiency and subnormal nucleoside phosphorylase activity: effect of zinc supplementation. Eur J Cancer Clin Oncol 1989, 25:973-976.

132. Wagner PA, Jernigan JA, Bailey LB, Nickens C, Brazzi GA: Zinc nutriture and cell-mediated immunity in the aged. Int J Vitam Nutr Res 1983, 53:94-101.

133. Fortes C, Forastiere F, Agabiti N, Fano V, Pacifici R, Virgili F, Piras G, Guidi L, Bartoloni C, Tricerri A, Zuccaro P, Ebrahim S, Perucci CA: The effect of zinc and vitamin $A$ supplementation on immune response in an older population. J Am Geriatr Soc 1998 , 46:19-26

134. Hodkinson CF, Kelly M, Alexander HD, Bradbury I, Robson PJ, Bonham MP, O'Connor JM, Coudray C, Strain JJ, Wallace JM: Effect of zinc supplementation on the immune status of healthy older individuals aged 55-70 years: the ZENITH Study. J Gerontol A Biol Sci Med Sci 2007, 62:598-608. 
135. Fabris N, Mocchegiani E, Amadio L, Zannotti M, Licastro F, Franceschi $C:$ Thymic hormone deficiency in normal ageing and Down's syndrome: is there a primary failure of the thymus? Lancet 1984, I:983-986.

136. Boukaiba N, Flament C, Acher S, Chappuis P, Piau A, Fusselier M, Dardenne $M$, Lemonnier D: A physiological amount of zinc supplementation: effects on nutritional, lipid, and thymic status in an elderly population. Am J Clin Nutr 1993, 57:566-572.

137. Bogden JD, Oleske JM, Lavenhar MA, Munves EM, Kemp FW, Bruening KS, Holding KJ, Denny TN, Guarino MA, Krieger LM: Zinc and immunocompetence in elderly people: effects of zinc supplementation for 3 months. Am J Clin Nutr 1988, 48:655-663.

138. Bogden JD, Oleske JM, Lavenhar MA, Munves EM, Kemp FW, Bruening KS, Holding KJ, Denny TN, Guarino MA, Holland BK: Effects of one year of supplementation with zinc and other micronutrients on cellular immunity in the elderly. J Am Coll Nutr 1990, 9:2|4-225.

139. Hodkinson CF, Kelly M, Coudray C, Gilmore WS, Hannigan BM, O'Connor JM, Strain JJ, Wallace JM: Zinc status and age-related changes in peripheral blood leukocyte subpopulations in healthy men and women aged 55-70 y: the ZENITH study. Eur J Clin Nutr 2005, 59(Suppl 2):S63-S67.

140. Kahmann L, Uciechowski P, Warmuth S, Plumakers B, Gressner AM, Malavolta M, Mocchegiani E, Rink L: Zinc supplementation in the elderly reduces spontaneous inflammatory cytokine release and restores T cell functions. Rejuvenation Res 2008, I I :227-237.

14 I. Kahmann L, Uciechowski P, Warmuth S, Malavolta M, Mocchegiani E, Rink L: Effect of improved zinc status on $T$ helper cell activation and $\mathrm{THI} / \mathrm{TH} 2$ ratio in healthy elderly individuals. Biogerontology 2006, 7:429-435.

142. Aydemir TB, Blanchard RK, Cousins RJ: Zinc supplementation of young men alters metallothionein, zinc transporter, and cytokine gene expression in leukocyte populations. Proc Natl Acad Sci USA 2006, 103:1699-1704.

143. Ortega RM, Requejo AM, Andres P, Lopez-Sobaler AM, Quintas ME, Redondo MR, Navia B, Rivas T: Dietary intake and cognitive function in a group of elderly people. Am J Clin Nutr 1997, 66:803-809.

144. Mocchegiani E, Malavolta M, Marcellini F, Pawelec G: Zinc, oxidative stress, genetic background and immunosenescence: implications for healthy ageing. Immun Ageing 2006, 3:6.

145. Maylor EA, Simpson EE, Secker DL, Meunier N, Andriollo-Sanchez M, Polito A, Stewart-Knox B, McConville C, O'Connor JM, Coudray C: Effects of zinc supplementation on cognitive function in healthy middle-aged and older adults: the ZENITH study. $\mathrm{Br}$ J Nutr 2006, 96:752-760.

146. Marcellini F, Giuli C, Papa R, Gagliardi C, Dedoussis G, Monti D, Jajte J, Giacconi R, Malavolta M, Mocchegiani E: Zinc in elderly people: effects of zinc supplementation on psychological dimensions in dependence of IL-6-174 polymorphism: a Zincage study. Rejuvenation Res 2008, I I :479-483.

147. Joseph JA, Shukitt-Hale B, Casadesus G, Fisher D: Oxidative stress and inflammation in brain aging: nutritional considerations. Neurochem Res 2005, 30:927-935.

148. Girodon F, Galan P, Monget AL, Boutron-Ruault MC, BrunetLecomte P, Preziosi P, Arnaud J, Manuguerra JC, Herchberg S: Impact of trace elements and vitamin supplementation on immunity and infections in institutionalized elderly patients: a randomized controlled trial. MIN. VIT. AOX. geriatric network. Arch Intern Med 1999, I 59:748-754.

149. Provinciali M, Montenovo A, Di Stefano G, Colombo M, Daghetta L, Cairati M, Veroni C, Cassino R, Della TF, Fabris N: Effect of zinc or zinc plus arginine supplementation on antibody titre and lymphocyte subsets after influenza vaccination in elderly subjects: a randomized controlled trial. Age Ageing 1998, 27:715-722.

150. Sandstead HH, Prasad AS, Penland JG, Beck FW, Kaplan J, Egger NG, Alcock NW, Carroll RM, Ramanujam VM, Dayal HH, Rocco CD, Plotkin RA, Zavaleta AN: Zinc deficiency in Mexican American children: influence of zinc and other micronutrients on $T$ cells, cytokines, and antiinflammatory plasma proteins. Am J Clin Nutr 2008, 88:1067-1073.

15I. Prasad AS, Brewer GJ, Schoomaker EB, Rabbani P: Hypocupremia induced by zinc therapy in adults. JAMA 1978, 240:2166-2168.
Publish with Biomed Central and every scientist can read your work free of charge

"BioMed Central will be the most significant development for disseminating the results of biomedical research in our lifetime. "

Sir Paul Nurse, Cancer Research UK

Your research papers will be:

- available free of charge to the entire biomedical community

- peer reviewed and published immediately upon acceptance

- cited in PubMed and archived on PubMed Central

- yours - you keep the copyright

Submit your manuscript here:

http://www.biomedcentral.com/info/publishing_adv.asp
BioMedcentral 